\title{
Life-threatening abdominal injury during a soccer game: a rare clinical case
}

\author{
Futbol maçında gelişen hayatı tehdit edici karın yaralanması: \\ Nadir bir klinik olgu
}

\author{
Eray KARA, ${ }^{1}$ Gökhan İÇÖZ, ${ }^{2}$ Sinan ERSIN,${ }^{2}$ Ahmet ÇOKER ${ }^{2}$
}

\begin{abstract}
Soccer (football) is a popular sport worldwide and can result in severe abdominal injuries. Nevertheless, the necessity of surgical intervention for abdominal organ injuries has been reported rarely. We report a case who was injured during a soccer game who underwent abdominal surgery. Distal subtotal pancreatectomy, splenectomy, cholecystectomy, and choledochotomy + T-tube drainage were performed. He was discharged on the postoperative seventh day without any complication.
\end{abstract}

Key Words: Abdominal injury; soccer; surgery.
Futbol dünyada yaygın bir spordur ve ciddi karın yaralanmalarına yol açabilir. Bununla birlikte, cerrahi girişim gerektirecek karın organı yaralanmaları nadiren bildirilmiştir. Futbol maçı esnasında yaralanan ve karın cerrahisi uygulanan bir olgu sunuldu. Hastaya distal pankreatektomi, splenektomi, kolesistektomi, kolodoktomi ve T tüp drenaj uygulandı. Hasta ameliyat sonrası yedinci gün komplikasyonsuz olarak taburcu edildi.

Anahtar Sözcükler: Karın yaralanması; futbol, cerrahi.
Over the past two decades, soccer (referred to as "football" in Europe) has rapidly increased in popularity, with nearly 80 million young and recreational players worldwide. ${ }^{[1]}$ This widespread participation has been accompanied by a large number of injuries. Soccer injuries are reported to be only one-fifth as frequent as and less severe than injuries sustained in American football. ${ }^{[2,3]}$ Intra-abdominal organ injuries due to sports traumas, especially in soccer, are relatively rare. Hereby, we present a case with splenic artery laceration and pancreas and gallbladder injuries due to being kneed in the abdomen during a football game.

\section{CASE REPORT}

An 18-year-old male football player complained of mild, chronic, non-colicky abdominal pain, vomiting and nausea following blunt abdominal trauma caused by being kneed in the abdomen. Although he felt fine immediately after the trauma, he was taken to the medical center 12 hours later. The physical signs on admission were abdominal pain with rebound tenderness in all quadrants, vomiting and nausea. The pain, which had been present approximately the last six hours, had gradually worsened. The patient's blood pressure was $120 / 70 \mathrm{~mm} \mathrm{Hg}$, with pulse of $100 / \mathrm{min}$. No anomalies were detected on abdominal X-ray, but ultrasonography and computerized tomography revealed enlargement and edema of pancreatic body and fluid collection within the pelvis (Fig. 1). The laboratory values of the patient were as follows: hematocrit: 40.6\%, white blood cell (WBC): $13700 / \mathrm{mm}^{3}$, aspartate aminotransferase (AST): $31 \mathrm{U} / \mathrm{ml}$, alanine aminotransferase (ALT): $30 \mathrm{U} / \mathrm{ml}$, lactate dehydrogenase (LDH): $461 \mathrm{U} / \mathrm{ml}$, and serum amylase: $1048 \mathrm{U} / \mathrm{ml}$. As a result, surgical intervention was decided.

On surgical exploration of the abdomen, a large hematoma entirely involving the transverse mesocolon, transection of the pancreatic body, laceration of splenic vessels, and partial hematoma in the gallblad-

${ }^{1}$ Department of General Surgery, Celal Bayar University, Faculty of Medicine, Manisa; ${ }^{2}$ Department of General Surgery, Ege University, Faculty of Medicine, Izmir, Turkey. İzmir. 


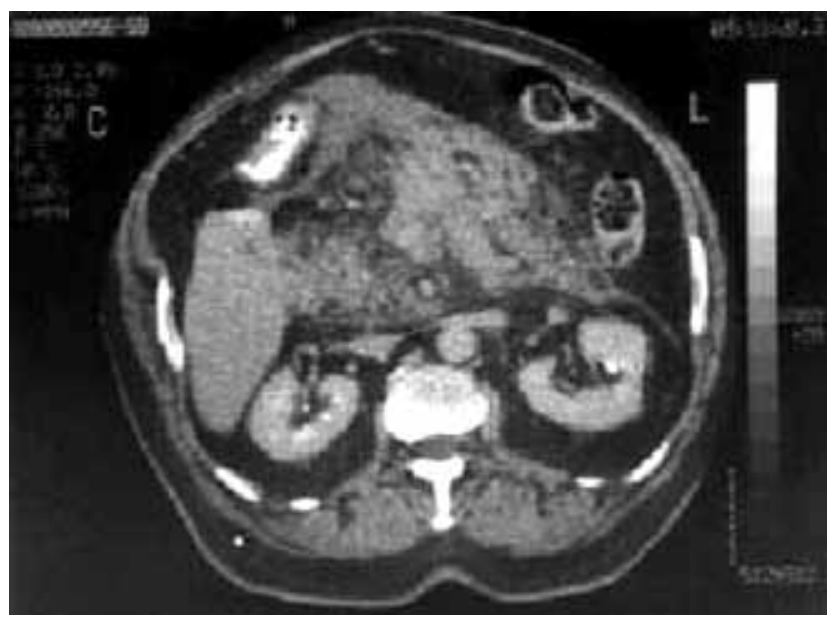

Fig. 1. Computed tomography demonstrates peripancreatic hemorrhage and pancreatic edema secondary to trauma.

der and extra-hepatic biliary system were detected. The liver parenchyma, periportal and retro-duodenal regions, external surfaces of the kidneys, renal pelvis, and mesentery of small bowel appeared normal. Following evacuation of the hematoma, distal subtotal pancreatectomy, splenectomy, cholecystectomy, and choledochotomy + T-tube drainage were performed. The postoperative course was uneventful and the patient was discharged on the seventh postoperative day.

\section{DISCUSSION}

Soccer is the most popular organized sport around the world and certainly in Turkey. ${ }^{[4]}$ Hence, injuries in soccer are likely to increase as more and more Turkish youth become involved in the sport. It has been reported that soccer contributed to nearly one-third of all sports injuries. ${ }^{[5,6]}$ Soft tissue injuries formed nearly two-thirds of all injuries, whereas bone and joint injuries comprised one-third or less. Intra-abdominal organ injuries have not been clearly reported due to a lack of data in the literature. Kurtoglu et al. ${ }^{[7]}$ reported four life-threatening soccer injuries consisting of two cervico-facial traumas causing epidural hematoma and C5-C6 anterior dislocation, one grade IV kidney injury and one grade IV spleen injury. Although the pancreatic injuries are seen with greater frequency today, pancreatic trauma is still uncommon. It is reported as accounting for $12 \%$ of all abdominal injuries, and nearly one-fourth of pancreatic injuries are caused by blunt abdominal trauma. ${ }^{[8,9]}$ Pancreatic injury in association with football is very rare. In 1985, Harrison et al. ${ }^{[10]}$ reported a case with isolated pancreatic transection in a football game. In our case, pancreatic injury was associated with other organ injuries, such that we had the opportunity to diagnose and treat immediately, since isolated pancreatic injuries are often overlooked. Injuries to the pancreas alone are treated according to the type of injury sustained. Total transection of the pancreas through the neck will necessitate resection.
In the present case, the distal pancreas was removed and the proximal aspect of the pancreas was closed with non-absorbable sutures. Isolated gallbladder, extra-hepatic bile duct or porta hepatis injuries due to external trauma are exceedingly rare, often require repair of the bile duct with or without drainage, and are usually associated with cholecystectomy. ${ }^{[11,12]}$ In the present case, we performed cholecystectomy with choledochotomy and T-tube drainage. The spleen is the most commonly injured organ in blunt abdominal trauma, though it was reported rarely in sports traumas. Korkut et al. ${ }^{[13]}$ had reported two cases of spleen ruptures due to football trauma to the abdomen. In our case, there was an active bleeding due to laceration of the splenic vasculature, and splenectomy was performed.

In conclusion, serious abdominal injuries resulting from sports are rare but increasing in number worldwide. ${ }^{[14-16]}$ The potential for misdiagnosis is significant and the consequences may be serious. Patients with abdominal pain should be taken very seriously and investigated with appropriate diagnostic equipment. In cases in which there is a serious concern about an intra-abdominal injury, transport of the patient, preferably to a trauma center, should be done rapidly. There should not be excessive delays in starting intravenous fluids or administering time-consuming procedures. ${ }^{[16-}$ ${ }^{21]}$ Since the early signs of injury may often go unrecognized, even in those cases progressing to shock and collapse, it is imperative that all clinicians be aware of such injuries.

\section{REFERENCES}

1. Ekblom B. Applied physiology of soccer. Sports Med 1986;3:50-60.

2. Pritchett JW. Cost of high school soccer injuries. Am J Sports Med 1981;9:64-6.

3. Pardon ET. Lower extremities are site of most soccer injuries. Phys Sports Med 1977;7:43-8.

4. Schmidt-Olsen S, Bünemann LK, Lade V, Brassøe JO. Soccer injuries of youth. Br J Sports Med 1985;19:161-4.

5. Chan KM, Fu F, Leung L. Sports injuries survey on university students in Hong Kong. Br J Sports Med 1984;18:195202.

6. Maehlum S, Daljord OA. Football injuries in Oslo: a oneyear study. Br J Sports Med 1984;18:186-90.

7. Kurtoğlu M, Dolay K, Güloğlu R, Necefli A, Cag M. Life threatening soccer injuries. Eur J Traum Emerg Surg 1999;22:37-9.

8. Jones RC. Management of pancreatic trauma. Am J Surg 1985;150:698-704.

9. Jurkovich GJ, Carrico CJ. Pancreatic trauma. Surg Clin North Am 1990;70:575-93.

10. Harrison JD, Branicki FJ, Makin GS. Pancreatic injury in association football. Injury 1985;16:232.

11. Feliciano DV, Bitondo CG, Burch JM, Mattox KL, Beall AC Jr, Jordan GL Jr. Management of traumatic injuries to the extrahepatic biliary ducts. Am J Surg 1985;150:705-9.

12. Andrén-Sandberg A, Alinder G, Bengmark S. Accidental lesions of the common bile duct at cholecystectomy. Pre- and 
perioperative factors of importance. Ann Surg 1985;201:32832.

13. Korkut MA, Kara E, Cevikel H, Akyıldız M, Ersin S, Ucar Y. Two cases of spleen ruptures in football traumas. Turk $\mathrm{J}$ Sports Med 1994;29;2:81-5.

14. Diamond DL. Sports-related abdominal trauma. Clin Sports Med 1989;8:91-9.

15. Ichikawa N, Taniguchi T, Shimada N. Sports injuries in judo. Kikan Kansetsu Geka 1984;1:91-2. [Abstract]

16. Houshian S. Traumatic duodenal rupture in a soccer player. Br J Sports Med 2000;34:218-9.

17. Ryan JM. Abdominal injuries and sport. Br J Sports Med
1999;33:155-60.

18. Lindenmann JM, Schmid D, Akovbiantz A. Jejunum perforation following blunt abdominal trauma-a case report. Schweiz Rundsch Med Prax 1994;83:857-60. [Abstrcat]

19.Zaydfudim V, Cotton BA, Kim BD. Pancreatic transection after a sports injury. J Trauma 2010;69:E33.

20. Quinlan JF, McCarthy CJ, McGlone B, Magee DJ. High grade splenic rupture in an elite Rugby Union player. J Sports Med Phys Fitness 2010;50:68-71.

21. Sacco E, Marangi F, Pinto F, D’Addessi A, Racioppi M, Gulino G, et al. Sports and genitourinary traumas. Urologia 2010;77:112-125. [Abstract] 